\title{
A LITERATURE REVIEW ON INDONESIA'S DERADICALIZATION PROGRAM FOR TERRORIST PRISONERS
}

\author{
I Gede Widhiana Suarda*
}

\author{
Criminal Law Department, Faculty of Law University of Jember, Jember \\ Jalan Kalimantan 37 Kampus Tegalboto Jember, Jawa Timur 68121
}

\begin{abstract}
After many terrorists are captured and receive prison sentences, Indonesia instituted a deradicalization program for terrorist prisoners. This article presents a review of the literature on Indonesia's deradicalization program for terrorist prisoners. Author concludes that First, there are some limitations among the agencies in achieving the goal of rehabilitation. Second, there is no agreement as to whether Indonesia 's program reflects disengagement or de-radicalization. Third, the program is currently developed and managed locally by prison directors consistent with a prison's circumstances and capability. Fourth, Indonesia has no measurement criteria for indicating the effectiveness of the program. Fifth, less attention has been paid to Indonesian prison officers who are implementing the program.
\end{abstract}

Key words: terrorism, terrorist prisoners, deradicalization.

\section{Intisari}

Setelah banyak teroris ditangkap dan menjalani pidana penjara, Indonesia mulai menjalankan program deradikalisasi terhadap narapidana teroris. Artikel ini bertujuan menyajikan sebuah kajian pustaka tentang program deradikalisasi Indonesia terhadap narapidana teroris. Kesimpulan dari artikel ini adalah Pertama, terdapat kelemahan kelembagaan terkait deradikalisasi narapidana teroris; Kedua, belum jelas apakah kebijakan penanganan terorisme mencerminkan pembebasan atau deradikalisasi narapidana teroris; Ketiga, program deradikalisasi dikelola secara lokal oleh kepala lembaga pemasyarakatan (Kalapas) sejalan dengan keadaan dan kemampuan lembaga pemasyarakatan (Lapas); Keempat, tidak ada ukuran pasti untuk mengukur efektivitas deradikalisasi; dan Kelima, minim perhatian pada lapas terkait program deradikalisasi.

Kata Kunci: terorisme, narapidana teroris, deradikalisasi.

\section{Pokok Muatan}

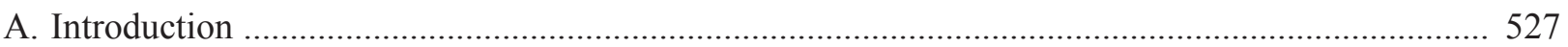

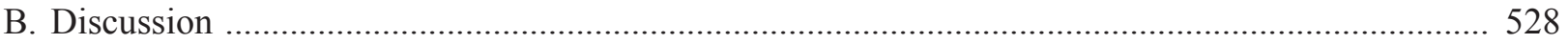

1. Terrorism in Indonesia: Incidents, Networks, and Future Threats ............................................ 528

2. Terrorist Prisoners in Indonesia: Facts and Figures ............................................................. 531

3. A Review on the Topic of Indonesia's Deradicalization Program for Terrorist Prisoners ........... 533

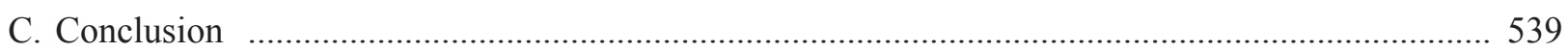

Correspondence address: igwsuarda@gmail.com / igedewidhiana.suarda@hdr.qut.edu.au. 


\section{A. Introduction}

Terrorist attacks indicate a significant threat to global security. The attacks occur in many countries, including Indonesia. Ongoing acts of terrorism in Indonesia are an indication that the country is vulnerable to this serious crime. Incidents have occurred in Aceh, Bali, Maluku, Sulawesi, and Sumatra. The first Bali bombing on the $12^{\text {th }}$ October 2002 marked a pivotal moment for the development of a criminal justice initiative in Indonesia. It led to the Indonesian National Police implementing a range of measures to improve detection, prevention, and enforcement against terrorism. ${ }^{1}$

As a result of these initiatives there are increased numbers of convicted terrorists in Indonesian prisons. According to the Indonesian National Police discussion paper entitled 'Law Enforcement in Indonesia' (2011) there were 695 terrorist suspects arrested and 519 convicted and imprisoned between 2002 and 2011. ${ }^{2}$ Of considerable concern is the reported number of terrorist recidivists. Petrus Reinhard Golose argued that many of the convicted terrorists repeated acts of terrorism, and were involved in radicalizing other inmates while imprisoned. ${ }^{3}$

However, it remains unclear how and why this recidivism and radicalization happens in Indonesian prisons. For example, it is not known whether former prisoners who commit terrorism acts after release were radicalized in prison, or were acting on established beliefs. Furthermore, it is unclear what supervisory prison models are in place to prevent repeat offending. Such questions raise numerous policy and practical issues for the Indonesian authorities, namely: the specific programs and personal development models that are implemented in prison; the ideology or theory that informs the best practice of these models; and how the Indonesian Prison Authority (IPA) evaluates or assesses the success of a model.

Even though a deradicalization program has been launched by the Indonesian government, questions and criticisms are still raised. The International Crisis Group (ICG), for example, recommended that the Indonesian Government accelerate efforts to put in place a system under the Corrections Directorate for identifying and monitoring high-risk detainees, both while in detention as well as after their release. ${ }^{4}$ Furthermore, ICG recommended improving supervision through upgrading the analytical capacity of correction staff. $^{5}$

When convicted terrorists Taufik bin Abdul Halim (hereafter Dani) and Edi Setiono (hereafter Abas) were sent to prison, their incarceration marked the first time that an Indonesian prison attempted the rehabilitation of terrorist prisoners. Dani and Abas had been found guilty by the Central Jakarta District Court as the perpetrators of the Plaza Atrium bombing in August 2001. ${ }^{6}$ They were jailed in Cipinang prison, Jakarta, and lived in the same cell and block with other 'ordinary' prisoners.

After the incident of the first Bali Bombing in 2002, Indonesia subsequently introduced AntiTerrorism Law (ATL). Due to the fact that many terror attacks occurred after the ATL was introduced, the number of terrorist inmates has increased sharply. Many criminals who commit terror attacks have since been convicted as terrorists. Taufik Andrie accurately argues that this was a period when

Galih Priatmodjo, 2010, Densus 88: The Uncover Squad, Narasi, Yogyakarta, p.5.

Mabes Polri, "Reformasi dan Optimalisasi Penegakan Hukum di Kepolisian Negara Republik Indonesia”, Paper, FGD Penegakan Hukum di Indonesia, Jakarta, 12 October 2011.

As stated in the seminar "From Radicalization to Terrorism" which held by Setara Institute in Jakarta, 25 January 2012. See: Berita Satu, "Petinggi BNPT: Deradikalisasi Belum Sukses", http://www.beritasatu.com/politik/27961-petinggi-bnpt-deradikalisasi-belum-sukses.html, accessed on 10 February 2014.

4 International Crisis Group, "How Indonesian Extremists Regroup", https://www.crisisgroup.org/asia/south-east-asia/indonesia/howindonesian-extremists-regroup, accessed on 15 November 2014.

Ibid.

6 Tempo, “Terror Bom di Indonesia (Beberapa di Luar Negeri) dari Waktu ke Waktu”, http://tempo.co.id/hg/timeline/2004/04/17/tml,2004041701,id.html, accessed on 15 November 2014. 
Indonesian prisons faced difficulties in dealing with terrorist prisoners. ${ }^{7}$ To make it worse, it was found that a terrorist prisoner became 'passive' actors for the next terror acts while behind bars. For example, Imam Samudra, a terrorist convicted after the first Bali bombing, had been found to be a 'passive' actor in the second Bali bombing. Communication between Noordin M. Top-the intellectual leader behind the attacks - occurred when Imam Samudra was imprisoned in Kerobokan prison. These issues faced by Indonesian prisons require investigation.

This article explores the issue of Indonesia's deradicalization approach for terrorist prisoners by reviewing relevant literature on this issue. The gap is identified in order to propose a new approach for future research. In line with these objectives, this article investigates three issues: (1) the trends of the crime of terrorism in Indonesia; (2) the facts and figures of terrorist prisoners in Indonesian prisons; and (3) the gaps in the literature on Indonesia's prison-based deradicalization program. Two major terms related to this article, deradicalization and terrorist prisoners, should be clarified. First, deradicalization is defined as "any initiative that tries to achieve a reduction of risk of re-offending through addressing the specific and relevant disengagement issues". ${ }^{8}$ Second, terrorist prisoners refers to those who are convicted by the Court for terrorism acts under their country's anti-terrorism laws, and as a consequence live in prisons or jails, regardless of the length of their imprisonment. ${ }^{9}$ In this sense, the term will not include: those who are categorized as 'suspected terrorists'; those who are being interrogated by the police; those awaiting trial or in trial sessions; or those who have the status of fugitives from acts of terrorism.

\section{B. Discussion \\ 1. Terrorism in Indonesia: Incidents, Networks, and Future Threats}

Bomb attacks in Indonesia began in 2000 with the targeting of churches, followed by several suicide bombings until 2005. Based on the number of victims and international impact, the most notorious attacks were: the first Bali bombing in 2002; the first Marriot Hotel bombing in Jakarta in 2003; the bombing of the Australian Embassy in 2004; and the second Bali bombing in 2005. ${ }^{10}$ As a result of subsequent investigations, in November 2005 the Indonesian National Police (INP) killed one of the most important masterminds behind these bombing attacks - Dr. Azahari Husin. ${ }^{11}$

Between 2005 and 2009 bomb attacks were controlled successfully by the INP, and Indonesia experienced no bombing incidents during this period. ${ }^{12}$ The effectiveness of the INP in preventing attacks from 2005-2009 was the result of improved investigation with a focus on prevention. Hence, the Jemaah Islamiyah (JI) cells could be dismantled, and some future attacks were prevented. Interestingly, the investigation's processes were also supported by Nasir bin Abas, "the former head of J's Mantiqi III and head of military training in the Southern Philippines who became disillusioned with the al-Qaeda campaign of terror against soft Western targets". ${ }^{13}$ His role remains vital because he provides valuable information for police investigations of JI and its operations.

However, in 2009 bombs exploded at the J.W. Marriott Hotel and the Ritz Carlton Hotel in

Taufik Andrie, "Kehidupan di Balik Jeruji: Terorisme dan Kehidupan Penjara di Indonesia”, Institute for International Peace Building Position Paper, Vol. 2, November, 2011, p. 6.

8 John Horgan and Kurt Braddock, "Rehabilitating the Terrorists?: Challenges in Assessing the Effectiveness of De-radicalization Programs", Terrorism and Political Violence, Vol. 22, No. 2, 2010, p. 280.

9 See: Article 1 point (32) of the Indonesian Code of Criminal Procedure (Kitab Undang-undang Hukum Pidana - KUHAP) and Article 1 point (7) of the the Indonesian Law No. 12 of 1995 on Correctional Institution.

10 Sarlito Wirawan Sarwono (Hereinafter referred to as Sarlito Wirawan Sarwono I), 2012, Terorisme di Indonesia: Dalam Tinjauan Psikologi, Pustaka Alvabet, Jakarta, p. 75

Galih Priatmodjo, Op. cit, p. 94

Ibid., p. 76.

Zachary Abuza, "The Rehabilitation of Jemaah Islamiyah Detainees in South East Asia: A Preliminary Assessment” in Tore Bjørgo and John Horgan, 2009, Leaving Terrorism Behind: Individual and Collective Disengagement, Routledge, Oxon, p. 198. 
Jakarta. The bombing at the J.W. Marriott Hotel was the second at that location, following an earlier attack in 2004. Several perpetrators were identified, including Indonesia's most wanted Islamist militant, Noordin M. Top. The authorities claimed that he was the mastermind behind the attack. ${ }^{14}$ Noordin was a fugitive after several bombing attacks, until he was killed in a shoot-out by the INP during a raid in Central Java in September 2009. Even though Noordin and Dr. Azahari Husin had been killed, Indonesia did not become secure from the threat of terrorism. Sydney Jones stated that:

It's a major success for the police but it doesn't mean, unfortunately, that the problem of terrorism is over. It's still unclear how many people were in Noordin's group and there are a number of fugitives still at large who have at least the potential to replace him as the leader of an al Qaeda-like organization. ${ }^{15}$

Indeed, attacks have still occurred since 2009 , but with a shift in both the methods and the targets. The perpetrators not only used bombs as a strategy to attack the targets, but also used firearms. Moreover, the attackers were not only focused on Western targets, but also on local ones. Heiduk noted that "Indonesian officials and government institutions have increasingly become targets". ${ }^{16}$ A failed bomb plot to assassinate former President, Yudhoyono, in 2010 is an example of this change in strategy. The plot failed when it was uncovered by police surveillance and two bomb makers were killed during the subsequent raid. As another example, Hamparan Perak police station in Sumatera Utara province was attacked and destroyed by several people with firearms in 2010, killing three police officers. ${ }^{17}$ Since this incident, several other police stations have been attacked by terrorists and more police officers shot and killed. In March, June, and August 2014, for instance, former Indonesian Police Chief, General Sutarman, declared that three police officers who died in Bima were shot by terrorists. ${ }^{18}$

Rather than attacking Western targets, therefore, evidence suggests that one of the main trends of terrorism in Indonesia since 2009 has been attacking the police (either by shooting police officers or destroying police stations). Another important trend to emerge during this period has been attacks on the public, regardless of whether they are Muslim or not. In April 2011, for example, there was a bomb attack on a mosque in the Cirebon police station complex, as well as an attack on the Christ Cathedral Church that was prevented by police. Later, in August 2013, the Vihara Ekayana Buddhist Centre in Jakarta was also the target of bombing attacks. ${ }^{19}$

To summarize, since 2009 the terrorists' have changed from attacking mostly Western targets to attacking specific targets such as police stations, churches, viharas, or even mosques. The finding of a list of viharas located in and around Jakarta which was printed by suspected terrorists (who were arrested in Jakarta and East Java in January 2014) indicates that targets are random. Taqwadin believes that this trend has been influenced by the change of al Qaeda's tactics since Ayman Al Zawahiri became the group's leader. ${ }^{20}$

The majority of people assume that JI is behind the bomb attacks in Indonesia, particularly the incidents from 2000 to 2005. During this

14 BBC, "Fugitive Linked to Jakarta Blasts", http://news.bbc.co.uk/2/hi/asia-pacific/8157104.stm, accessed on 12 October 2014.

15 Reuters, "Q+A: Noordin Mohammad Top and Islamic Militancy in Indonesia", http://www.reuters.com/article/2009/09/17/us-indonesiamilitants-qanda-sb-idUSTRE58G2OR20090917, accessed on 12 October 2014.

16 Felix Heiduk, "Between a Rock and a Hard Place: Radical Islam in Post-Suharto Indonesia", International Journal of Conflict and Violence, Vol. 6, No. 1, 2012, p. 33.

17 Ari Anggada, "Penyerang Polsek Hamparan Perak Tak Beradab", http://nasional.news.viva.co.id/news/read/179449-penyerang-polsekhamparan-perak-tak-beradab, accessed on 12 October 2014.

18 Merdeka, "Kapolri Sebut Penembak Polisi di Bima Teroris", http://www.merdeka.com/peristiwa/kapolri-sebut-penembak-polisi-di-bimateroris.html, accessed on 12 October 2014.

19 Kompas, "Kabareskrim: Ledakan di Vihara Ekayana Perbuatan Teroris", http://nasional.kompas.com/read/2013/08/05/0030095/Kabareskrim. Ledakan.di.Vihara.Ekayana.Perbuatan.Teroris, accessed on 13 October 2014.

20 Daniel Akbar Taqwadin, "Trend Baru Terorisme di Indonesia", http://www.academia.edu/5838920/Trend_Baru_Terorisme_di_Indonesia, accessed on 12 October 2014. 
period the perpetrators came from JI, which was established in 1993 by Abdullah Sungkar and Abu Bakar Bassyir, as stated by Sarlito Wirawan. ${ }^{21}$ This group has a relationship with al Qaeda, indicated by the programs of Abdullah Sungkar and Abu Bakar Bassyir sending the Bali bombers group to 'pre-jihad training' on the border of Afghanistan and Pakistan, and to jihad fronts in Afghanistan, the Philippines, Ambon, and Poso. ${ }^{22}$ JI also has close links to other Islamist Militant groups throughout South East Asia, such as the Abu Sayyaf Group (ASG) in the Philippines. ${ }^{23}$ Importantly, JI's main goal is to establish a pan-Islamic country in South East Asia. ${ }^{24}$

In relation to the types of terrorist target, it could be argued that terrorism in Indonesia is religiously motivated due to the fact that JI pursue the replacement of the established government with an Islamic government. Furthermore, JI is striving for the creation of a pan-Islamic government in Indonesia despite the opposition of the majority of Indonesian Muslims to this idea.

Types of terrorism vary across the emerging literature in the fields of sociology, criminology, and peace studies. Gus Martin, for instance, divides terrorism into five categories, namely: state terrorism; dissident terrorism; criminal terrorism; international terrorism; and religious terrorism. ${ }^{25}$ State terrorism (terrorism 'from above') is terrorism committed by established governments against their perceived enemies, either internationally or nationally, while dissident terrorism (terrorism 'from below') is terrorism committed by various nongovernmental actors against governments, specific groups, or other perceived enemies. ${ }^{26}$ Criminal terrorism is terrorism in which the goal is financial or political gain, or both; whereas international terrorism is terrorism in which the goal is a global effect, or the target is an international symbol. ${ }^{27}$ Religious terrorism is "terrorism motivated by an absolute belief that an otherworldly power has sanctioned - and commanded - the application of terrorist violence for the greater glory of faith". ${ }^{28}$

On the other hand, critical scholars state that categorizing terrorism can be more of an obstacle than an aid to rigorous research. However, they also argue that attempts to categorize terrorism can be beneficial in gaining understanding of this phenomenon. ${ }^{29}$ Therefore, categorizing the acts of terrorism in Indonesia into a specific typology is important for a better understanding of the problems. Based on the current situation, as well as the body of literature and empirical research, the acts of terrorism in Indonesia can be categorized as 'religious terrorism' according to the definition stated previously. For instance, Martin identified Laskar Jihad, the armed Islamic group in Indonesia, as a religious terrorist group along with Aum Shinrikyo, Lord's Resistance Army, Palestine Islamic Jihad, Hamas, Al Qaeda, Abu Sayyaf, Jammu-Kashmir groups, Sikh groups, and Algerian/North African cells. ${ }^{30}$

According to Heather S. Gregg, religious terrorism can be divided into three subcategories based on their goals: "fomenting the apocalypse, creating a religious government, and religiously cleansing a state". ${ }^{31}$ Because the goal is to establish an Islamic government in Indonesia, JI's intention

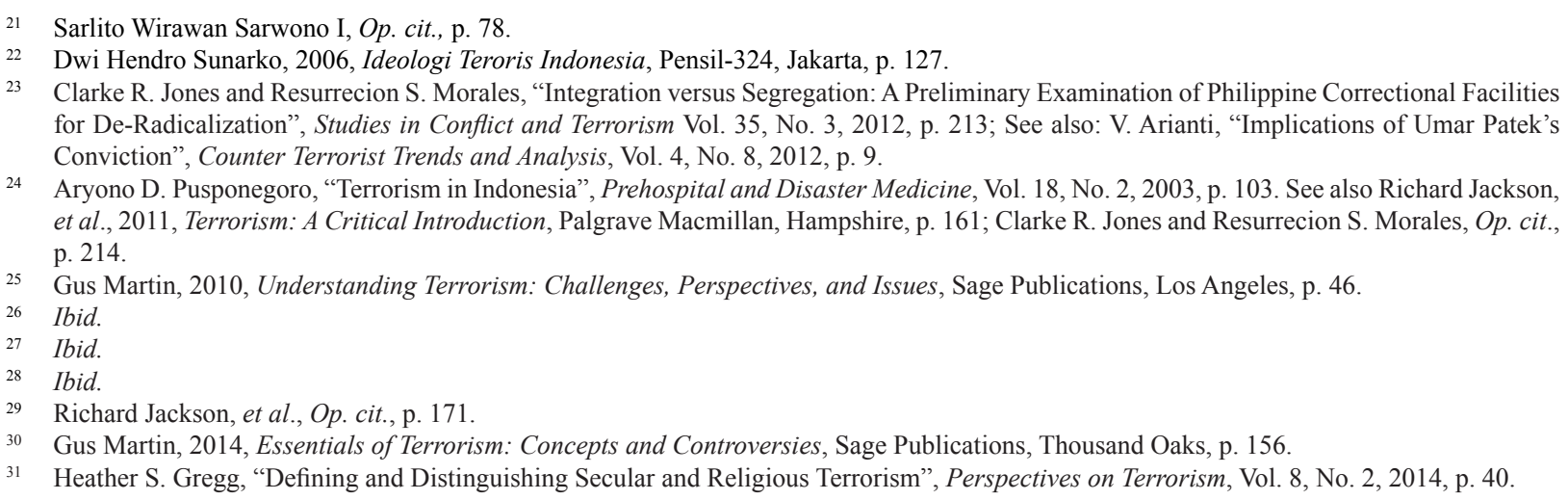

24 Aryono D. Pusponegoro, "Terrorism in Indonesia", Prehospital and Disaster Medicine, Vol. 18, No. 2, 2003, p. 103. See also Richard Jackson, et al., 2011, Terrorism: A Critical Introduction, Palgrave Macmillan, Hampshire, p. 161; Clarke R. Jones and Resurrecion S. Morales, Op. cit., p. 214. 
identifies them as an example of the second subcategory.

On the other hand, Bilveer Singh has warned that blaming incidents only on JI is not accurate because "there are many regionallybased terrorists groups that have nothing to do with the JI". ${ }^{32}$ Related to this statement, a report by Ansyaad Mbai, the former Head of the Indonesian National Anti-Terrorism Agency (BNPT - Badan Nasional Penanggulangan Terorisme), offers support for Singh's view. Furthermore, Ansyaad Mbai stated that there are various concentrations of terrorist groups in Indonesia, including: Qoidah Aminah in North Sumatera and Aceh; Mujahid Indonesia Barat in Lampung and Java; Islamic State for Indonesia (NII) in South Kalimantan and Tasikmalaya; Mujahid Indonesia Timur in Poso; Asmar in Sulawesi; Walid group in Ambon; Jamaah Ansharut Tauhid (JAT) in Bali; Bima networks in West Nusa Tenggara; and Solo networking group. ${ }^{33}$ These groups demonstrate the widespread nature of new terrorist cells and their networks in Indonesia, whether they have links to JI or not.

This situation indicates Indonesia remains under threat of terrorism in the future. Even though in a study has concluded that "Indonesia is the least risky, least volatile, and most resilient" ${ }^{\prime 3}$ when compared with the Philippines and Thailand, many experts (Sarlito Wirawan; ${ }^{35}$ Carl Ungerer; ${ }^{36}$ ICG $^{37}$ ) predict that terrorist attacks will likely occur in Indonesia in the future. It does mean that terrorist attacks may still occur in Indonesia in the future, even if there is greater risk elsewhere in the region.

\section{Terrorist Prisoners in Indonesia: Facts and Figures}

Data concerning the exact number of convicted terrorists in Indonesian prisons vary between reports or articles. In some articles (Abuza; ${ }^{38}$ Horgan and Braddock ${ }^{39}$ ) it is estimated that more than 300 individuals were sent to prison by 2007 , while Ungerer estimates that around twothirds of nearly 600 suspects were convicted between 2000 and $2010 .{ }^{40}$ Similarly, the IRIN, a newspaper published in Nairobi, reported that 600 out of 830 were sentenced for conducting acts of terrorism in the decade $2002-2012 .{ }^{41}$ Notwithstanding the different timeframes, the inconsistent data reported in these sources is confusing.

On the official website of the Directorate General of Corrections, the number of terrorist convicts is presented only after 2011. The number of terrorist prisoners in the years 2011 to 2015 is $109^{42}, 204^{43}, 276^{44}, 277^{45}$, and $216^{46}$ respectively. The data show that by August 2013 the number of terrorism prisoners had increased to nearly three times the number in August 2011, as illustrated in Figure 2.1 below.

32 Bilveer Singh, “The Challenge of Militant Islam and Terrorism in Indonesia”, Australian Journal of International Affairs, Vol. 58, No. 1, 2004, p. 65 .

33 Tempo, "Peta Konsentrasi Jaringan Teroris di Indonesia", http://www.tempo.co/read/news/2014/08/10/078598475/Peta-KonsentrasiJaringan-Teroris-di-Indonesia, accessed on 13 October 2014.

34 Gentry White, Michael D. Porter, Lorraine Mazerolle, "Terrorism Risk, Resilience, and Volatility: A Comparison of Terrorism Patterns in Three Southeast Asian Countries", Journal Quantitative Criminology, Vol. 29, 2013, p. 315.

35 Sarlito Wirawan Sarwono I, Op. cit., p. 84.

36 Carl Ungerer, "Jihadists in Jail: Radicalisation and the Indonesian Prison Experience", Australian Strategic Policy Institute - Special Report, Issue 40, May 2011, p. 17.

37 International Crisis Group, "How Indonesian Extremists Regroup", https://www.crisisgroup.org/asia/south-east-asia/indonesia/howindonesian-extremists-regroup, accessed on 15 November 2014.

38 Zachary Abuza, Op. cit., p. 198.

39 John Horgan and Kurt Braddock, Op. cit., p. 274.

40 Carl Ungerer, Op. cit., p. 11.

41 IRIN, "Deradicalization - is Indonesia's approach working?", http://www.irinnews.org/analysis/2012/10/15/\%E2\%80\%9Cderadicalization\% E2\%80\%9D-indonesia\%E2\%80\%99s-approach-working, accessed on 13 Oktober 2014.

42 Sistem Database Pemasyarakatan Direktorat Jenderal Pemasyarakatan RI, "Data Terakhir Jumlah Khusus Penghuni Perkanwil”, http://smslap. ditjenpas.go.id/public/krl/current/monthly/year/2011/month/8, accessed on 23 June 2016.

43 Ibid.

44 Ibid.

45 Ibid.

46 Ibid. 


\section{Graph 1. The Number of Terrorist Prisoners in Indonesia (2011 to 2015)}

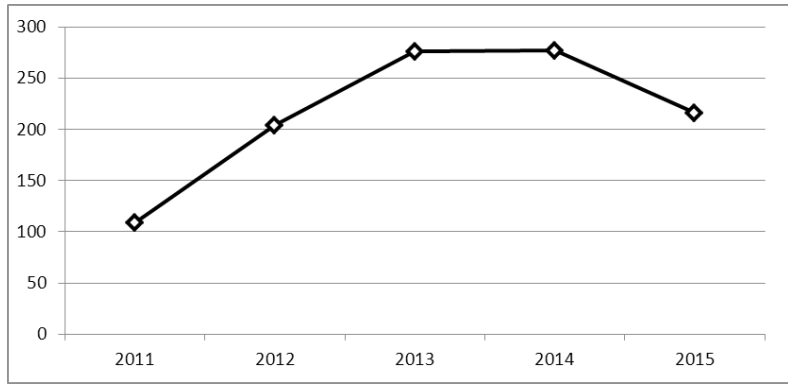

Source: Sistem Database Pemasyarakatan Direktorat Jenderal Pemasyarakatan Republik Indonesia, 2016.

These prisoners are not isolated in one or two special prisons, but dispersed among several prisons across the provinces. By August 2015 the data show that 216 convicted terrorists were dispersed among 33 prisons and detention centers throughout the islands (see Table 1). ${ }^{47}$ Pasir Putih Nusakambangan prison holds the largest concentration of terrorist inmates at 37 individuals, followed by Cipinang prison at 23 individuals. Additionally, the data indicate that there is only one female terrorist held in Indonesian jails.

\section{Table 1. The Distribution of Terrorist Prisoners}

\section{in Indonesian Prisons and Detention Centers}

\begin{tabular}{cllc}
\hline No. & $\begin{array}{c}\text { Prison/Detention } \\
\text { Center }\end{array}$ & \multicolumn{1}{c}{ Province } & $\begin{array}{c}\text { Terrorist } \\
\text { prisoners }\end{array}$ \\
\hline 1 & $\begin{array}{l}\text { Batu Nusakam- } \\
\text { bangan Prison }\end{array}$ & Central Java & 19 \\
2 & Cipinang Prison & Jakarta & 23 \\
3 & Cirebon Prison & West Java & 11 \\
4 & Madiun Prison & East Java & 2 \\
5 & Medan Prison & North Sumatera & 1 \\
6 & Palembang Prison & South Sumatera & 1 \\
7 & Semarang Prison & Central Java & 18 \\
8 & Surabaya Prison & East Java & 12 \\
9 & Tangerang Prison & Banten & 13 \\
10 & Banda Aceh Prison & Aceh & 1 \\
11 & Besi Nusakam- & Central Java & 4 \\
& bangan Prison & West Java & 19 \\
12 & Cibinong Prison & West
\end{tabular}

\begin{tabular}{|c|c|c|}
\hline 13 & Karawang Prison & West Java \\
\hline 14 & Kediri Prison & East Java \\
\hline 15 & $\begin{array}{l}\text { Kembang Kuning } \\
\text { Nusakambangan } \\
\text { Prison }\end{array}$ & Central Java \\
\hline 16 & Magelang Prison & Central Java \\
\hline 17 & Palu Prison & Central Sulawesi \\
\hline 8 & Pamekasan Prison & East Java \\
\hline 9 & $\begin{array}{l}\text { Pasir Putih Nusa- } \\
\text { kambangan Prison }\end{array}$ & Central Java \\
\hline 0 & $\begin{array}{l}\text { Permisan Nusa- } \\
\text { kambangan Prison }\end{array}$ & Central Java \\
\hline 21 & Salemba Prison & Jakarta \\
\hline 2 & Kuningan Prison & West Java \\
\hline 3 & Subang Prison & West Java \\
\hline 4 & Garut Prison & West Java \\
\hline & Ciamis Prison & West Java \\
\hline 6 & Cianjur Prison & West Java \\
\hline 7 & Indramayu Prison & West Java \\
\hline 8 & Lumajang Prison & East Java \\
\hline 9 & $\begin{array}{l}\text { Cipinang Deten- } \\
\text { tion Center }\end{array}$ & Jakarta \\
\hline 0 & $\begin{array}{l}\text { Wonosobo Deten- } \\
\text { tion Center }\end{array}$ & Central Java \\
\hline & $\begin{array}{l}\text { Jepara Detention } \\
\text { Center }\end{array}$ & Central Java \\
\hline & $\begin{array}{l}\text { Sanggan Detention } \\
\text { Center }\end{array}$ & West Kalimantan \\
\hline & $\begin{array}{l}\text { Tangerang Wom- } \\
\text { en's Prison }\end{array}$ & Banten \\
\hline \multicolumn{3}{|c|}{ Total } \\
\hline
\end{tabular}

Source: Sistem Database Pemasyarakatan Direktorat Jenderal Pemasyarakatan Republik Indonesia, 2016.

Compared to the number of all convicted prisoners under the charge of special criminal acts in Indonesian prisons, Table 1 indicates that the number of terrorism prisoners is small. Specifically, of 74,449 prisoners convicted of special criminal acts by August 2015, the number of terrorist prisoners was only $216 .^{48}$ Thus, the percentage of prisoners convicted of terrorist offences is no more than one percent of the total number of prisoners held under special criminal acts.

These facts and figures for convicted terrorists are similar to the trends in other countries.

47 Sistem Database Pemasyarakatan Direktorat Jenderal Pemasyarakatan RI, "Data Terakhir Jumlah Khusus Penghuni Per-UPT Pada Kanwil", http://smslap.ditjenpas.go.id/public/krl/current/monthly/kanwil/all/year/2015/month/8/page/, accessed on 23 June 2016. 
For example, the Netherlands had only five terrorism prisoners in $2010^{49}$, while Australia held 21 convicted terrorists in $2011,{ }^{50}$ and Canada held 18 convicted terrorists in 2015. ${ }^{51}$ Despite these relatively small totals, Andrew Silke argues that "when such prisoners do start to appear in the prison system their impact can be out of all proportion to their number", a concern that raises the issue of recruitment and radicalization of 'ordinary' prisoners. $^{52}$ Similarly, with respect to suspected terrorists, Alec Walen has argued that "they are predicted to pose a threat larger than that of almost all other criminals". 53

Data about the extent of recidivism among those involved in terrorism acts in Indonesia, on the other hand, is unclear. Indeed, official data on recidivism with regard to acts of terrorism is not available yet. As highlighted in the introduction, Indonesian officials claim that many convicted terrorists repeated acts of terrorism, but the official number of recidivism cases for acts of terrorism has not been provided. Several studies (Jones; ${ }^{54}$ Ungerer ${ }^{55}$ ) have underlined this lack of clarity, even though it has been revealed that recidivism rates for terrorism acts are notable in Indonesia.

\section{A Review on the Topic of Indonesia's Deradicalization Program for Terrorist Prisoners}

\section{a. Terrorist Prisoners and Its Treat- ment}

Terrorist prisoners are not the same as other criminals. ${ }^{56}$ Rather, they are 'special' because this type of prisoner carries an ideology. ${ }^{57}$ A review conducted by Pressman and Flockton confirmed that there are significant differences between terrorists, violent extremists, and non-ideologically motivated violent offenders. ${ }^{58}$

Pressman and Flockton pointed out that even though terrorists and violent extremists have similarities in using violence to further political, religious, and ideological aims, the acts of violent extremists commonly have no "intention to cause fear and terror in civilian populations or decision makers". ${ }^{59}$ The authors point to violent anti-abortionists as an example of a group that underlines their view. This group intend to cause enormous destructions to public facilities, such as property, buildings, vehicles, and hospitals, but "they have not demonstrated an interest in indiscriminate civilian killing, or maximum diffuse destruction" ${ }^{60}$ In contrast, this psychological intention is a common objective of terrorist attacks. ${ }^{61}$

As a consequence of these differences

49 Peter R. Neumann, 2010, Prisons and Terrorism; Radicalisation and De-radicalisation in 15 Countries, International Centre for the Study of Radicalisation and Political Violence, London, pp. 17-18.

50 Louise E. Porter and Mark R. Kebbel, "Radicalization in Australia: Examining Australia's Convicted Terrorists", Psychiatry Psychology and Law, Vol. 18, No. 2, 2011, p. 212.

51 Jeffrey Monaghan, "Criminal Justice Policy Transfer and Prison Counter-radicalization: Examining Canadian Participation in the Roma-Lyon Group”, Canadian Journal of Law and Society, Vol. 30, No. 3, 2015, p. 385.

52 Andrew Silke (Ed), 2014, Prisons, Terrorism, and Extremism: Critical Issues in Management, Radicalisation and Reform, Routledge, Oxon, p. 3.

53 Alec Walen, "A Unified Theory of Detention, with Application to Preventive Detention for Suspected Terrorists", Maryland Law Review, Vol. 70, No. 4, 2011, p. 872.

54 Clarke R. Jones, "Are Prisons Really Schools for Terrorism? Challenging the Rhetoric on Prison Radicalization", Punishment and Society, Vol. 16, No. 1, 2014, p. 87.

55 Carl Ungerer, Op. cit., p. 17.

56 Liran Goldman, "From Criminals to Terrorists: the US Experience of Prison Radicalisation", in Andrew Silke (Ed), 2014, Prisons, Terrorism, and Extremism: Critical Issues in Management, Radicalisation and Reform, Routledge, Oxon, p. 48.

57 Rohan Gunaratna, "Terrorist Rehabilitation: A Global Imperative", Journal of Policing, Intelligence and Counter Terrorism, Vol. 6, No. 1, 2011, p. 67.

58 D. Elaine Pressman and John Flockton, "Violent Extremist Risk Assessment: Issues and Application of the VERA-2 in a High-Security Correctional Setting”, in Andrew Silke (Ed), 2014, Prisons, Terrorism, and Extremism: Critical Issues in Management, Radicalisation and Reform, Routledge, Oxon, pp. 123-125.

59 Ibid., p. 124

60 Ibid.

61 Ibid. 
between terrorists and other criminals, terrorist prisoners should be rehabilitated under a specific program. Although Mullin has observed that there are opportunities to adopt best practices from the rehabilitative literature on ordinary prisoners, he also noted that "the content of criminal and terrorist rehabilitation programs will always differ". ${ }^{62}$

A specific de-radicalization program for terrorist prisoners has been implemented in several countries in order to achieve the goal of rehabilitation, and to stop the spread of radicalization in prisons. Saudi Arabia, for example, has a strategy called Prevention, Rehabilitation, and Aftercare (PRAC). In general, the program is recognized as a "soft" approach to terrorist prisoners within the concept of reform and transformation. ${ }^{63}$ In another example, the United Kingdom has launched CONTEST (the government's counter-terrorism strategy) and the revised PREVENT strategy. ${ }^{64}$

On the one hand, de-radicalization programs in several countries display similarities, or at least have the same approach or pattern. The countries which have implemented a similar pattern or approach to dealing with convicted terrorists are France, the Netherlands, Spain, the United Kingdom, and the United States. ${ }^{65}$ These countries' programs seem to focus on security, with only a limited awareness of promoting reform. ${ }^{66}$ On the other hand, these countries' approaches can be found to differ. For instance, of the five countries named, only the Netherlands implemented 'concentration' principles, whereby all terrorist prisoners are held in one place at the high security prisons in Vaugh. However, the remaining four countries applied dispersal and (partial) concentration policies. ${ }^{67}$

Alternatively, in the Philippines, a deradicalization program exists, but the policy is designed and implemented differently across the correctional system. For example, in the New Bilibid Prison (NBP) convicted terrorists are integrated with ordinary inmates, whereas in the Metro Manila District Jail (MMDJ) they are separated from the general prison population. ${ }^{69}$ To sum up, in terms of de-radicalization programs worldwide, while every country has their own approach, each country's program contains both similarities and/or significant differences with those of other countries.

b. The Nature of Indonesia's Deradicalization Program for Terrorist Prisoners

Through the prisons and detention centers, Indonesia has also run a deradicalization program for terrorist prisoners. However, Indonesia's program for convicted terrorists is not just following the global trend as implemented in other countries. Arguably, the foundation of Indonesia's distinct program is underpinned by two principal factors: (1) that Indonesia has terrorist prisoners, and (2) that there is an indication of the spread of radicalization in Indonesian prisons. Moreover, as mentioned earlier, experts and studies conclude that Indonesia remains under the threat of terrorism even

62 Sam Mullins, "Rehabilitation of Islamist Terrorists: Lesson from Criminology", Dynamics of Asymetric Conflict: Pathways toward terrorism and genocide, Vol. 3, No. 3, 2010, p. 162.

63 Marisa Porges, "Saudi Arabia's "Soft" Approach to Terrorist Prisoners", in Andrew Silke (Ed), 2014, Prisons, Terrorism, and Extremism: Critical Issues in Management, Radicalisation and Reform, Routledge, Oxon, p. 169.

${ }^{64}$ Richard Pickering, "Terrorism, Extremism, Radicalisation and the Offender Management System in England and Wales", in Andrew Silke (Ed), 2014, Prisons, Terrorism, and Extremism: Critical Issues in Management, Radicalisation and Reform, Routledge, Oxon, p. 161.

65 Peter R. Neumann, Op. cit., p. 13.

66 Ibid.

67 Ibid., p. 18.

68 Clarke R. Jones and Resurrecion S. Morales, Op. cit., p. 219. 
though some of the most wanted terrorists have been killed or imprisoned. Therefore, the possibility of having terrorist prisoners will remain.

Indonesia's deradicalization program for terrorist prisoners has been implemented by eitherprison services or other governmental agencies such as the INP. According to Taufik Andrie, ${ }^{69}$ deradicalization program in Indonesian prisons could be identified by several activities, such as providing conflict management training (CMT) or inviting an ulama (Islamic scholar) from Indonesia Clerics Assembly (Majelis Ulama Indonesia - MUI) to delivering a speech and discussion with terrorist prisoners. Yet, there are some prions that hold convicted terrorist have not specific deradicalization program as identified by Taufik Andrie. ${ }^{70}$ The INP's deradicalization program also focusses on 'soft' strategy by getting terrorist prisoners who were detained in Jakarta police headquarters and former terrorist prisoners who have renounced indiscriminate violence "to rethink armed struggle". ${ }^{71}$

Among these institutions, the program is coordinated by BNPT, which was established in 2010 based on President's Regulation Number 46. Ironically, even though the program is coordinated by BNPT, some studies (Sarlito Wirawan; ${ }^{72}$ Milda Istiqomah $^{73}$ ) stressed that the involvement of many agencies in the implementation of the program has drawbacks in achieving the goals of rehabilitation. To cope with these problems, Ungerer have recommended that the coordination between BNPT and prison services should be improved in their efforts to rehabilitate convicted terrorists. ${ }^{74}$

De-radicalization programs in Indonesian prisons are currently developed and managed locally by prison directors consistent with a prison's circumstances and capability. ${ }^{75}$ Based on fieldwork conducted in 13 prisons and detention centers in Indonesia, Taufik Andrie concluded that most of those prisons did not have a specific program for rehabilitating or de-radicalizing terrorist prisoners. ${ }^{76}$ Only two prisons were considered to have adequate programs: Porong (Surabaya) Prison and Semarang Prison. ${ }^{77}$

In line with the rehabilitation initiatives for terrorist convicts, the literature has shown that this can involve disengagement, de-radicalization, or both (Horgan and Braddock $;^{78}$ Mullins $;{ }^{79}$ Garry Hill $\left.{ }^{80}\right)$. De-radicalization is related to psychological change in terrorists' ideology, while disengagement focuses on behavioral change. In addition, both of the programs can be implemented either at a group (collective) level or an individual level. ${ }^{81}$

After an examination of Indonesia's deradicalization program which is implemented either by INP or Indonesian prisons, some researchers (Sulatri Osman; ${ }^{82}$ Sarlito

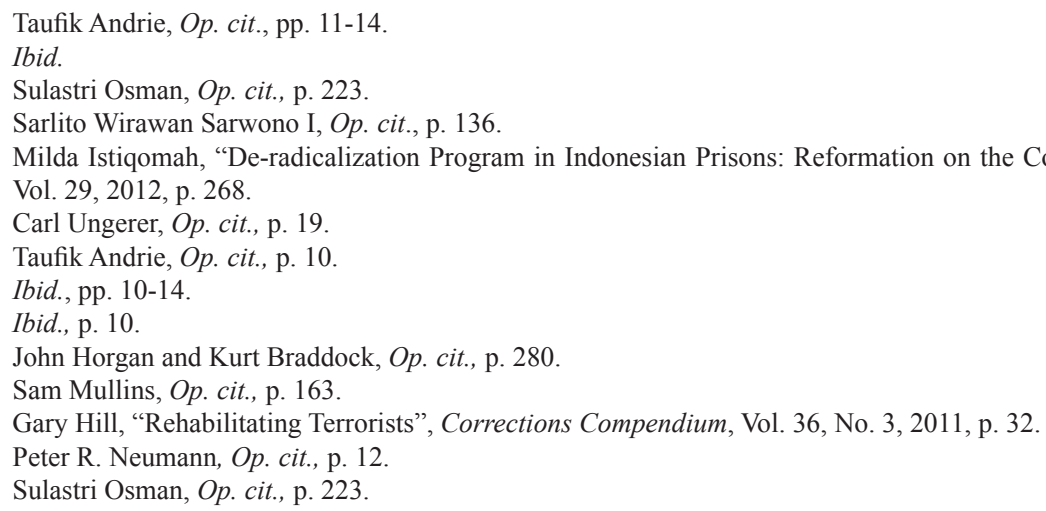


Wirawan; ${ }^{83}$ Horgan and Braddock; ${ }^{84}$ Abuza ${ }^{85}$ ) argue that Indonesia's practices in managing terrorist prisoners reflect disengagement rather than de-radicalization. Meanwhile, Schmid states that Indonesia's program is a combination of individual de-radicalization and collective de-radicalization. ${ }^{86}$ In a study on radicalization and de-radicalization in 15 countries, Neumann identified Indonesia as a country that deploys individual deradicalization and disengagement programs along with Afghanistan, the Philippines, Saudi Arabia, Singapore, and Yemen. ${ }^{87}$ Regardless of which programs are best suited to Indonesia's approach, all agree that the noticeable features of Indonesia's program are: (1) utilizing a former terrorist, Nasir bin Abbas, to re-educate terrorism prisoners; and (2) providing monetary incentives or economic assistance to captured terrorists, including their families. ${ }^{88}$

Discussion of the outcomes of Indonesia's de-radicalization program reveals disagreement about its efficacy. While research has shown that Indonesian prisons can be assessed positively for their de-radicalization initiatives (Magnus Ranstorp, 2009), ${ }^{89}$ a new study conducted by Horgan and Braddock (2010) argues that such assessments of initiatives that focus on monetary incentives are "inaccurate and certainly premature to consider this true de-radicalization". ${ }^{90}$ Moreover, Hasan and Yasin's investigation (2012) concluded that the weakness in the prison system has allowed incarcerated terrorists to "continue their contribution to the extremist's long term strategy". ${ }^{91}$ It is indicated by incarcerated extremists' publications through various articles and books on pro-violence ideology. Despite such articles and books being small in number, "the potential of such publications to radicalize the broader community should not be underestimated". ${ }^{2}$

With respect to how terrorist prisoners are housed, implementation depends on a prison's capability and circumstances. It is a local initiative which is established by the prison director. As stated by Jones, it means that Indonesia has "no single strategy for managing terrorist offenders". ${ }^{93}$ For example, in Cirebon prison, terrorist prisoners are prevented from interacting with other terrorist prisoners, whereas in Cibinong prison they are given the freedom to communicate with each other. Then again, in Cipinang prison, terrorist inmates are placed in a special block where there is also great opportunity to communicate. ${ }^{94}$ Theoretically, these methods could be classified as a mix of isolation and separation..$^{95}$

Sarlito Wirawan Sarwono I, Op. cit., p. 133.

John Horgan and Kurt Braddock, Op. cit., pp. 273-275.

Zachary Abuza, Op. cit., p. 198.

86 Alex P. Schmid, 2013, Radicalisation, De-Radicalisation, Counter-Radicalisation: A Conceptual Discussion and Literature Review, International Centre for Counter-Terrorism, The Hague, p. 41.

87 Peter R. Neumann, Op. cit., pp. 47-58.

88 Theresa N. Eckard, 2014, Prison-based Deradicalization for Terrorist Detainees: An Analysis of Programmatic Religious Re-education and Systematic Institutionalization and their Impact on Achieving Deradicalization, Dissertation, Northern Illinois University, Illinois, p. 156.

89 Magnus Ranstorp, 2009, Preventing Violent Radicalization and Terrorism: The Case of Indonesia, Swedish National Defence College, Stockholm, p. 18.

90 John Horgan and Kurt Braddock, Op. cit., pp. 267 and 269.

91 Muhammad Haniff Hasan and Nur Azlin Mohamed Yasin, "Indonesian Prisons: A Think Tank for Terrorist", Counter Terrorist Trends and Analysis, Vol. 4, Issue 8, 2012, p. 12.

Ibid., p. 11.

3 Clarke R. Jones, Loc. cit.

94 Direktorat Jenderal Pemasyarakatan RI, "Ditjen PAS Gelar Rapat Koordinasi Persiapan Pembinaan dan Penempatan Napi Teroris", http:// www.ditjenpas.go.id/ditjen-pas-gelar-rapat-koordinasi-persiapan-pembinaan-dan-penempatan-napi-teroris/, accessed on 21 September 2014.

95 According to Neumann there are three models of distribution for this prisoner population: "namely whether they should all be held in one place (concentration); whether they should be separated from the general prison population (separation); and if they should be isolated from each other (isolation)". See: Peter R. Neumann, Op. cit., p. 17. 
Currently, Indonesia has established a special prison for terrorist prisoners in Sentul, Bogor. This special prison is called Sentul prison. ${ }^{96}$ The Director General of Corrections, I Wayan Dusak, ${ }^{97}$ stated that this special prison will hold terrorist prisoners who are categorized as low-risk terrorist prisoners. On the one hand, establishing a special prison for terrorist prisoners in Sentul marks a new direction for the Indonesian government in dealing with the issue of rehabilitation for terrorist prisoners. On the other hand, a question that is why this special prison is needed for terrorist prisoners in Indonesia must be examined otherwise it could be ineffective in countering and preventing terrorism.

\section{c. A Research Gap and Future Re- search Approach on the Topic of In- donesia's Deradicalization Program for Terrorist Prisoners}

A considerable amount of studies on the topic of deradicalization program for terrorist prisoners in the Indonesian context is available in the literature. Various identical studies have been identified. From my literature review, existing studies on such topic could be divided into two major groups: 'the program' and 'the terrorist prisoners'. This division is based on the 'angle' of discussion or from what aspects the program is viewed. From the program means that prison-based dearadicalization program is examined from the program itself, such as the implementation of the program or the program components analysis. Meanwhile, from the terrorist prisoner means that deradicalization program is examined from terrorist prisoners' perspectives, such as investigation on how terrorist prisoners' responses to the program or to what extent their involvement in the program.

Firstly, studies on Indonesia's prisonbased deradicalization program that are focused on the program itself have been conducted by scholars and experts on this field (Eckard; $;{ }^{98}$ Johnston; ${ }^{99}$ Istiqomah; ${ }^{100}$ Nurezki; ${ }^{101}$ ICG; ${ }^{102}$ Rabasa, Pettyjohn, Ghez, and Boucek ${ }^{103}$ ). Findings and discussions are widely available in the literature. Indonesia's prison-based deradicalization program is selected either for comparative analysis or case study analysis. For example, Eckard ${ }^{104}$ examines prison-based deradicalization program in Indonesia, Saudi Arabia, Yemen dan Western Europe. Then the programs in those countries were compared to the U.S. programs in Iraq and Afghanistan. Similar to Eckard, Johnston ${ }^{105}$ and Rabasa et $\mathrm{al}^{106}$ also select Indonesia's prison-based dearadicalization program to be analyzed along with other countries. Slightly different with Eckard, those studies did not compare Indonesia's prison-based deradicalization program with other selected countries. Johnston and Rabasa et al employ a

96 Direktorat Jenderal Pemasyarakatan RI, “Januari 2017, Lapas Khusus Deradikallisasi Sentul Mulai Beroperasi”, http://www.ditjenpas.go.id/ januari-2017-lapas-khusus-deradikallisasi-sentul-mulai-beroprasi/, accessed on 8 Desember 2014.

$97 \quad$ Ibid.

98 Theresa N. Eckard, Op. cit., pp. 156-178

99 Amanda K. Johnston, 2009, Assesing the Effectiveness of Deradicalization Programs on Islamist Extremists, Thesis, Naval Posgraduate School, California, pp.39-48.

100 Milda Istiqomah, Op. cit. pp. 268-273.

101 Lendra Putra Nurezki, 2013, A Hazy Redemption: Can Radicalisation Work in Indonesia?, Thesis, National University of Singapore, Singapore, pp.77-86.

102 International Crisis Group, "Deradicalisation" and Indonesian Prisons", https://www.crisisgroup.org/asia/south-east-asia/indonesia/ deradicalisation-and-indonesian-prisons, accessed on 21 September 2014.

103 Angel Rabasa, Stacie L. Pettyjohn, Jeremy J. Ghez, and Christopher Boucek, 2010, Deradicalizing Islamist Extremists, RAND, Santa Monica, pp. 106-116.

104 Theresa N. Eckard, Op. cit., p. 7.

105 Amanda K. Johnston, Loc. cit.

106 Angel Rabasa, Stacie L. Pettyjohn, Jeremy J. Ghez, and Christopher Boucek, Loc. Cit. 
separate single case study analysis to each national deradicalization program, including Indonesia's program.

In its report, $\mathrm{ICG}^{107}$ explores several practical aspects of Indonesia's program, particularly on how terrorist prisoner are housed and what strategies have been applied by the Indonesian authorities in dealing with terrorist prisoners. Identical to ICG's focus, both Nurezki ${ }^{108}$ and Istiqomah ${ }^{109}$ analyze Indoensia's prison-based deradicalization program and its implementation. Although they are on the same focus, Nurezki and Istiqomah provide different recommendation for preventing recidivism on terrorism acts. Nurezki ${ }^{110}$ argues that the best strategy of deradicalization in Indonesia is disengagement while Istiqomah ${ }^{111}$ argues that a reformation on the correctional system is required.

Secondly, empirical qualitative studies on Indonesia's prison-based deradicalization program that is viewed from convicted terrorist experiences and perspectives are also available (Sukabdi; ${ }^{112}$ Ungerer ${ }^{113}$ Andrie; ${ }^{114}$ Sarwono $\left.{ }^{115}\right)$. The focus in these studies is diverse. For example, Ungerer ${ }^{116}$ have examined terrorist prisoners' involvement and experiences in prison-based deradicalization program, while Sarwono ${ }^{117}$ have proposed a course of deradicalization program as a preliminary study for former terrorist prisoners. In a report, entitled 'Life Behind Bars: Terrorism and Prison Life in Indonesia', Andrie argues that most of the participants refuse to involve in deradicalization program. ${ }^{118} \mathrm{He}$ does not only examine terrorist prisoners' response but also examine whether the prisons have run deradicalization program or not. ${ }^{119}$ In this sense, his study could also be included in the group that observed prison-based deradicalization program from the program.

A recent study, which is conducted by Sukabdi, shows a direct and specific discussion on the relationship between the program and terrorist prisoners. She selects terrorist prisoners and former terrorist prisoners as the object of research. In the findings, Sukabdi identifies five substantial matters: "terror activists' behavior transformation process in Indonesia, critical areas of development needed in changing terrorism perpetrators' behaviors, key elements in rehabilitation, criterion for successful rehabilitation, and parameters of effective deradicalization". ${ }^{120}$ Additionally, this study reveals a positive result that there is possibility of behavior transformation from pro-violence to nonviolence. In order to rehabilitate Indonesian terrorist prisoners, Sukabdi argues that there are six dimensions of critical areas of development needed, namely: social skills, personal skills, vocational skills, spiritual

107 International Crisis Group, "Deradicalisation" and Indonesian Prisons", https://www.crisisgroup.org/asia/south-east-asia/indonesia/ deradicalisation-and-indonesian-prisons, accessed on 21 September 2014.

108 Lendra Putra Nurezki, Loc. Cit.

109 Milda Istiqomah, Loc. Cit.

110 Lendra Putra Nurezki, Op. cit., 137-138.

11 Milda Istiqomah, Op. cit., p. 273.

112 Zora A. Sukabdi, "Terrorism in Indonesia: A Review on Rehabilitation and Deradicalization", Journal of Terrorism Research, Vol. 6, Issue 2, 2015, pp. 36-56.

113 Carl Ungerer, Op. cit., pp. 11-19.

114 Taufik Andrie, Op. cit., p. 14-24.

115 Sarlito Wirawan Sarwono I, Op. cit., pp. 44-59. See also: Sarlito Wirawan Sarwono (Hereinafter referred to as Sarlito Wirawan Sarwono II), 2013, Menakar Jiwa Mantan Teroris Melalui Tes Davido CHaD, Salemba Humanika, Jakarta, pp. 43-56.

116 Carl Ungerer, Op. cit., pp. 14-17.

117 Sarlito Wirawan Sarwono II, Op. cit., p. 44.

118 Taufik Andrie., Op. cit. 17-18.

119 Ibid., pp. 11-14.

120 Zora A. Sukabdi, Op. cit., p 52. 
maturity, domestic skills, and contextual insight. ${ }^{121}$

To sum up, after reviewing the literature on the topic of Indonesia's deradicalization program for terrorist prisoners, a research gap could be identified that is a lack of studies focused on Indonesian prison officers as the implementer of the program. Even though numerous studies have been devoted to 'the program' and 'the terrorist prisoners' but less attention has been paid to 'the prison officers'. Consequently, conducting a research that is focused on the prison officers' point of view is worthwhile to extend the body of literature on this topic. Besides extending the body of literature, it is beneficial to develop an integrated understanding on the complexity of the implementation of the program. In addition, an examination of this end of deardicalization program may prove invaluable for future policy and practice.

In connection to the grouping of the existing studies on the topic of Indonesia's deradicalization program for terrorist prisoners, this new approach would extend the group from two into three major groups: (1) the program; (2) the terrorist prisoners; and (3) the prison officers. Furthermore, within the context of prison officers' point of view, the focus of the research could be narrowed into a specific issue. There are many issues related to prison officers' role in the implementation of deradicalization program. To select a specific one it could be started by investigating a current phenomenon and/or by investigating relevant literature indeed.

\section{Conclusion}

The number of terrorist prisoners in
Indonesian prisons is significantly lower than other types of prisoner. The number, however, cannot be disregarded. Indonesian prisons have to cope with at least two critical issues. The first is how to prevent the spread of radicalization in prisons, as evidenced by terrorist inmates' successful radicalization of ordinary inmates such as Yuli Harsono, Hamzah, and Gema Awal Ramadhan ${ }^{122}$. To make matters worse, prison guards are also targets for radicalization, as in the case of Beni Irawan ${ }^{123}$. The second issue is how to change inmates' radical beliefs during their imprisonment. The seriousness of this problem is highlighted by the 18 known recidivism cases between 2009 and $2010^{124}$. In other words, terrorist inmates retain their radical beliefs and engage in terrorist activities after release. To deal with this issue, a de-radicalization program for terrorist prisoners has been instituted by the Indonesian government. In this article, the literature on Indonesia's de-radicalization program for terrorist prisoners has been reviewed. The main goals of this review are to understand the nature of the program, identify the research gap, and to indicate approaches for future research. Following the review, a number of conclusions can be drawn. First, even though many governmental agencies get involved in the deradicalization program (e.g., Directorate General of Corrections; INP), the program is coordinated by BNPT. The involvement of many agencies in the implementation of the program has some limitations in achieving the goal of rehabilitation, such as a "lack of coordination and over-division". ${ }^{125}$ Second, there is no agreement among experts as to whether Indonesia's program reflects disengagement or deradicalization. Nevertheless, there is agreement that the noticeable features of Indonesia's program are: (1) the utilizing of a former terrorist, Nasir bin Abbas, to re-educate terrorist prisoners; and (2) the provision of monetary incentives or economic

21 Ibid., p. 46.

22 Agus Surya Bakti, 2014, Darurat Terorisme: Kebijakan Pencegahan, Perlindungan, dan Deradikalisasi, Daulat Press, Jakarta, p. 193.

123 International Crisis Group (ICG), 2012, "Deradicalisation” and Indonesian Prisons”, https://www.crisisgroup.org/asia/south-east-asia/ indonesia/deradicalisation-and-indonesian-prisons, accessed on 21 September 2014.

124 Taufik Andrie, Op. cit., p. 10.

125 Milda Istiqomah, Loc. cit. 
assistance to captured terrorists, including their families.

Third, the program is currently developed and managed locally by prison directors consistent with a prison's circumstances and capability. Consequently, each prison's capability not only impacts its ability to implement the de-radicalization program, but also how terrorist prisoners are housed. This indicates that Indonesia has no national strategy concerning how terrorist prisoners are housed in each prison. Even though a special prison for terrorist prisoners has been established, policy on how this type of prisoner is housed in other prisons remains on the prison director initiative. Fourth, discussion of the outcomes of the de-radicalization program in Indonesian prisons reveals disagreement about its efficacy. While one study provides a positive assessment of Indonesia's de-radicalization program, others argue that Indonesia's initiative has been unsuccessful. Moreover, Indonesia has no measurement criteria for indicating the effectiveness of the program.

Fifth, although a considerable amount of studies on the topic of deradicalization program for terrorist prisoners in the Indonesian context is available in the literature, less attention has been paid to Indonesian prison officers who are implementing the program at the coalface. After reviewing the literature, existing studies on this topic could be divided into two major groups: the program and the terrorist prisoners. There is a lack of study focused on the implementer of the program. Therefore, a research that is focused on Indonesian prison officers' point of view pertaining to the implementation of prison-based deradicalization program program is critical. Besides extending the body of literature, this new approach would develop an integrated understanding on the program implementation; and it may prove invaluable for future policy and practice.

\section{BIBLIOGRAPHY}

\section{A. Books}

Bjørgo, Tore and Horgan, 2009, Leaving Terrorism Behind: Individual and Collective Disengagement, Routledge, Oxon.

Bakti, Agus Surya, 2014, Darurat Terorisme: Kebijakan Pencegahan, Perlindungan, dan Deradikalisasi, Daulat Press, Jakarta.

Jackson, Richard, et al., 2011, Terrorism: A Critical Introduction, Palgrave Macmillan, Hampshire.

Martin, Gus, 2010, $3^{\text {rd }}$ ed, Understanding Terrorism: Challenges, Perspectives, and Issues, Sage Publications, Los Angeles. , 2014, $3^{\text {rd }}$ ed, Essentials of Terrorism: Concepts and Controversies, Sage Publications, Thousand Oaks.

Neumann, Peter R., 2010, Prisons and Terrorism; Radicalisation and De-radicalisation in 15 Countries, International Centre for the Study of Radicalisation and Political Violence,
London.

Priatmodjo, Galih, 2010, Densus 88: The Uncover Squad, Narasi, Yogyakarta.

Rabasa, Angel, et al., 2010, Deradicalizing Islamist Extremists, RAND, Santa Monica.

Ranstorp, Magnus, 2009, Preventing Violent Radicalization and Terrorism: The Case of Indonesia, Swedish National Defence College, Stockholm.

Sarwono, Sarlito Wirawan, 2012, Terorisme di Indonesia: Dalam Tinjauan Psikologi, Pustaka Alvabet, Jakarta. , 2013, Menakar Jiwa Mantan Teroris Melalui Tes Davido CHaD, Salemba Humanika, Jakarta.

Schmid, Alex P., 2013, Radicalisation, DeRadicalisation, Counter-Radicalisation: A Conceptual Discussion and Literature Review, International Centre for CounterTerrorism, The Hague. 
Silke, Andrew (Ed), 2014, Prisons, Terrorism, and Extremism: Critical Issues in Management, Radicalisation and Reform, Routledge, Oxon.Sunarko, Dwi Hendro, 2006, Ideologi Teroris Indonesia, Pensil-324, Jakarta.

\section{B. Anthologies}

Goldman, Liran, "From Criminals to Terrorists: the US Experience of Prison Radicalisation", in Andrew Silke (Ed), 2014, Prisons, Terrorism, and Extremism: Critical Issues in Management, Radicalisation and Reform, Routledge, Oxon.

Porges, Marisa, "Saudi Arabia's 'Soft' Approach to Terrorist Prisoners", in Andrew Silke (Ed), 2014, Prisons, Terrorism, and Extremism: Critical Issues in Management, Radicalisation and Reform, Routledge, Oxon.

Pickering, Richard, "Terrorism, Extremism, Radicalisation and the Offender Management System in England and Wales", in Andrew Silke (Ed), 2014, Prisons, Terrorism, and Extremism: Critical Issues in Management, Radicalisation and Reform, Routledge, Oxon.

Pressman, D. Elaine and Flockton, John, "Violent Extremist Risk Assessment: Issues and Application of the VERA-2 in a HighSecurity Correctional Setting", in Andrew Silke (Ed), 2014, Prisons, Terrorism, and Extremism: Critical Issues in Management, Radicalisation and Reform, Routledge, Oxon.

\section{Journal Articles}

Arianti, V., "Implications of Umar Patek's Conviction", Counter Terrorist Trends and Analysis, Vol. 4, Issue 8, 2012.

Gregg, Heather S., "Defining and Distinguishing Secular and Religious Terrorism", Perspectives on Terrorism, Vol. 8, No. 2, 2014.

Gunaratna, Rohan, "Terrorist Rehabilitation: A Global Imperative", Journal of Policing,
Intelligence and Counter Terrorism, Vol. 6, No. 1, 2011.

Hasan, Muhammad Haniff and Yasin, Nur Azlin Mohamed, "Indonesian Prisons: A Think Tank for Terrorist", Counter Terrorist Trends and Analysis, Vol. 4, Issue 8, 2012.

Heiduk, Felix, "Between a Rock and a Hard Place: Radical Islam in Post-Suharto Indonesia", International Journal of Conflict and Violence, Vol. 6, No. 1, 2012.

Hill, Gary, "Rehabilitating Terrorists", Corrections Compendium, Vol. 36, No. 3, 2011.

Horgan, John and Braddock, Kurt, "Rehabilitating the Terrorists?: Challenges in Assessing the Effectiveness of De-radicalization Programs", Terrorism and Political Violence, Vol. 22, No. 2, 2010.

Istiqomah, Milda, "De-radicalization Program in Indonesian Prisons: Reformation on the Correctional Institution", US-China Law Review, Vol. 29, 2012.

Jones, Clarke R. "Are Prisons Really Schools for Terrorism? Challenging the Rhetoric on Prison Radicalization", Punishment and Society, Vol. 16, No. 1, 2014.

Jones, Clarke R. and Morales, Resurrecion S., "Integrationversus Segregation:APreliminary Examination of Philippine Correctional Facilities for De-Radicalization", Studies in Conflict and Terrorism Vol. 35, No. 3, 2012.

Maliki, "Implementasi Pembinaan Melalui Program Rehabilitasi dan Reintegrasi Sosial Bagi Narapidana Terorisme", Jurnal Magister Ilmu Hukum Udayana, Vol. 3, No. 2, 2013.

Monaghan, Jeffrey, "Criminal Justice Policy Transfer and Prison Counter-radicalization: Examining Canadian Participation in the Roma-Lyon Group", Canadian Journal of Law and Society, Vol. 30, No. 3, 2015.

Mullins, Sam, "Rehabilitation of Islamist Terrorists: Lesson from Criminology", Dynamics of Asymetric Conflict: Pathways toward terrorism and genocide, Vol. 3, No. 3, 2010.

Porter, Louise E. and Kebbel, Mark R., 
"Radicalization in Australia: Examining Australia's Convicted Terrorists", Psychiatry, Psychology and Law, Vol. 18, No. 2, 2011.

Pusponegoro, Aryono D. "Terrorism in Indonesia", Prehospital and Disaster Medicine, Vol. 18, No. 2, 2003.

Singh, Bilveer, "The Challenge of Militant Islam and Terrorism in Indonesia", Australian Journal of International Affairs, Vol. 58, No. 1, 2004.

Sukabdi, Zora A., "Terrorism in Indonesia: A Review on Rehabilitation and Deradicalization". Journal of Terrorism Research, Vol. 6, Issue 2, 2015.Walen, Alec, "A Unified Theory of Detention, with Application to Preventive Detention for Suspected Terrorists", Maryland Law Review, Vol. 70, No. 4, 2011.

White, Gentry, Michael D. Porter, Lorraine Mazerolle, "Terrorism Risk, Resilience, and Volatility: A Comparison of Terrorism Patterns in Three Southeast Asian Countries", Journal Quantitative Criminology, Vol. 29, 2013.

\section{Paper}

Andrie, Taufik, "Kehidupan di Balik Jeruji: Terorisme dan Kehidupan Penjara di Indonesia", Institute for International Peace Building Position Paper, Vol. 2, November, 2011.

Mabes Polri, "Reformasi dan Optimalisasi Penegakan Hukum di Kepolisian Negara Republik Indonesia", Paper, FGD Penegakan Hukum di Indonesia, Jakarta, 12 October 2011.

Ungerer, Carl, Jihadists in Jail: Radicalisation and the Indonesian Prison Experience, Australian Strategic Policy Institute - Special Report, Issue 40, May 2011.

\section{E. Internet Articles}

Anggada, Ari, "Penyerang Polsek Hamparan Perak Tak Beradab", http://nasional.news.viva. co.id/news/read/179449-penyerang-polsek- hamparan-perak-tak-beradab, accessed on 12 October 2014.

BBC, "Fugitive Linked to Jakarta Blasts", http:// news.bbc.co.uk/2/hi/asia-pacific/8157104. stm, accessed on 12 October 2014.

Berita Satu, "Petinggi BNPT: Deradikalisasi Belum Sukses", http://www.beritasatu.com/ politik/27961-petinggi-bnpt-deradikalisasibelum-sukses.html, accessed on 10 February 2014.

International Crisis Group, "Deradicalisation" and Indonesian Prisons", https://www. crisisgroup.org/asia/south-eastasia/ indonesia/deradicalisation-and-indonesianprisons, accessed on 21 September 2014. , "How Indonesian Extremists

Regroup", https://www.crisisgroup.org/asia/ south-east-asia/indonesia/how-indonesianextremists-regroup, accessed on 15 November 2014.

IRIN, "Deradicalization - is Indonesia's approach working?", http://www.irinnews.org/analys is $/ 2012 / 10 / 15 / \% E 2 \% 80 \% 9$ Cderadicalizati on\%E2\%80\%9D-indonesia\%E2\%80\%99sapproach-working, accessed on 13 Oktober 2014.

Kompas, "Kabareskrim: Ledakan di Vihara Ekayana Perbuatan Teroris", http://nasional. kompas.com/read/2013/08/05/0030095/ Kabareskrim.Ledakan.di.Vihara.Ekayana. Perbuatan.Teroris, accessed on 13 October 2014.

Merdeka, "Kapolri Sebut Penembak Polisi di Bima Teroris", http://www.merdeka.com/peristiwa/ kapolri-sebut-penembak-polisi-di-bimateroris.html, accessed on 12 October 2014.

Reuters, "Q+A: Noordin Mohammad Top and Islamic Militancy in Indonesia", http:// www.reuters.com/article/2009/09/17/ us-indonesia-militants-qanda-sbidUSTRE58G2OR20090917, accessed on 12 October 2014.

RI, Sistem Database Pemasyarakatan Direktorat Jenderal Pemasyarakatan, "Data Terakhir 
Jumlah Khusus Penghuni Perkanwil”, http:// smslap.ditjenpas.go.id/public/krl/current/ monthly/year $/ 2015 /$ month $/ 8$, accessed on 23 June 2016.

RI, Sistem Database Pemasyarakatan Direktorat Jenderal Pemasyarakatan, "Data Terakhir Jumlah Khusus Penghuni Per-UPT Pada Kanwil", http://smslap.ditjenpas.go.id/ public/krl/current/monthly/kanwil/all/ year/2015/month/8/page/, accessed on 23 June 2016.

Satu, Berita, "Petinggi BNPT: Deradikalisasi Belum Sukses", http://www.beritasatu.com/ politik/27961-petinggi-bnpt-deradikalisasibelum-sukses.html, accessed on 10 February 2014.

Taqwadin, Daniel Akbar, "Trend Baru Terorisme di Indonesia", http://www.academia. edu/5838920/Trend_Baru_Terorisme_di Indonesia, accessed on 12 October 2014.

Tempo, "Peta Konsentrasi Jaringan Teroris di Indonesia", http://www.tempo.co/read/news/ 2014/08/10/078598475/Peta-Konsentrasi-
Jaringan-Teroris-di-Indonesia, accessed on 13 October 2014.

Tempo, "Terror Bom di Indonesia (Beberapa di Luar Negeri) dari Waktu ke Waktu", http://tempo. co.id/hg/timeline/2004/04/17/tml,2004041701,id.html, accessed on 15 November 2014.

\section{F. Research Reports}

Eckard, Theresa N., 2014, Prison-based Deradicalization for Terrorist Detainees: An Analysis of Programmatic Religious Re-education and Systematic Institutionalization and their Impact on Achieving Deradicalization, Dissertation, Northern Illinois University, Illinois.

Johnston, Amanda K., 2009, Assesing the Effectiveness of Deradicalization Programs on Islamist Extremists, Thesis, Naval Posgraduate School, California.

Nurezki, Lendra Putra, 2013, A Hazy Redemption: Can Radicalisation Work in Indonesia?, Thesis, National University of Singapore, Singapore. 